J. Dairy Sci. 97:1872-1872

http://dx.doi.org/10.3168/jds.2014-97-3-1872

(c) American Dairy Science Association ${ }^{\circledR}, 2014$.

\title{
Erratum to "Technical note: Selection of suitable reference genes for studying gene expression in milk somatic cell of yak (Bos grunniens) during the lactation cycle" (J. Dairy Sci. 97:902-910)
}

W. L. Bai, R. H. Yin, S. J. Zhao, W. Q. Jiang, R. L. Yin, Z. J. Ma, Z. Y. Wang, Y. B. Zhu, G. B. Luo, R. J. Yang, and Z. H. Zhao

The mention of supplemental materials on page 906 should have referenced Supplemental Table S2, not Supplemental Table S1. All supplemental files for this article can be accessed here: http://dx.doi.org/10.3168/ jds.2012-6437.

\section{REFERENCES}

Bai, W. L., R. H. Yin, S. J. Zhao, W. Q. Jiang, R. L. Yin, Z. J. Ma, Z. Y. Wang, Y. B. Zhu, G. B. Luo, R. J. Yang, and Z. H. Zhao. 2014 Technical note: Selection of suitable reference genes for studying gene expression in milk somatic cell of yak (Bos grunniens) during the lactation cycle. J. Dairy Sci. 97(2):902-910. 